\title{
Temporal changes in photoreactivity of dissolved organic carbon and implications for aquatic carbon fluxes from peatlands
}

\author{
Amy E. Pickard ${ }^{1,2}$, Kate V. Heal ${ }^{1}$, Andrew R. McLeod ${ }^{1}$, and Kerry J. Dinsmore ${ }^{2}$ \\ ${ }^{1}$ School of GeoSciences, Alexander Crum Brown Road, King's Buildings, The University of Edinburgh, \\ Edinburgh, EH9 3FF, UK \\ ${ }^{2}$ Centre for Ecology \& Hydrology, Bush Estate, Penicuik, EH26 0QB, UK \\ Correspondence to: Amy E. Pickard (amy.pickard@ed.ac.uk)
}

Received: 16 July 2016 - Discussion started: 5 August 2016

Revised: 12 February 2017 - Accepted: 1 March 2017 - Published: 4 April 2017

\begin{abstract}
Aquatic systems draining peatland catchments receive a high loading of dissolved organic carbon (DOC) from the surrounding terrestrial environment. Whilst photoprocessing is known to be an important process in the transformation of aquatic DOC, the drivers of temporal variability in this pathway are less well understood. In this study, $8 \mathrm{~h}$ laboratory irradiation experiments were conducted on water samples collected from two contrasting peatland aquatic systems in Scotland: a peatland stream and a reservoir in a catchment with high percentage peat cover. Samples were collected monthly at both sites from May 2014 to May 2015 and from the stream system during two rainfall events. DOC concentrations, absorbance properties and fluorescence characteristics were measured to investigate characteristics of the photochemically labile fraction of DOC. $\mathrm{CO}_{2}$ and $\mathrm{CO}$ produced by irradiation were also measured to determine gaseous photoproduction and intrinsic sample photoreactivity. Significant variation was seen in the photoreactivity of DOC between the two systems, with total irradiation-induced changes typically 2 orders of magnitude greater at the highDOC stream site. This is attributed to longer water residence times in the reservoir rendering a higher proportion of the DOC recalcitrant to photo-processing. During the experimental irradiation, $7 \%$ of DOC in the stream water samples was photochemically reactive and direct conversion to $\mathrm{CO}_{2}$ accounted for $46 \%$ of the measured DOC loss. Rainfall events were identified as important in replenishing photoreactive material in the stream, with lignin phenol data indicating mobilisation of fresh DOC derived from woody vegetation in the upper catchment. This study shows that peatland catchments produce significant volumes of aromatic DOC
\end{abstract}

and that photoreactivity of this DOC is greatest in headwater streams; however, an improved understanding of water residence times and DOC input-output along the source to sea aquatic pathway is required to determine the fate of peatland carbon.

\section{Introduction}

DOC is transported from terrestrial environments to aquatic systems, where it plays an important role in carbon (C) cycling. Biogeochemical transformations of DOC via microbial and photochemical pathways impact significantly on aquatic $\mathrm{C}$ cycles, with up to $55 \%$ of $\mathrm{C}$ exported as DOC to freshwaters estimated to be lost to the atmosphere as $\mathrm{CO}_{2}(\mathrm{Cole}$ et al., 2007; Tranvik et al., 2009; Cory et al., 2014). These estimates suggest that the $\mathrm{C}$ sink strength of the land surface globally has been overestimated, as the role of freshwater systems in the biogeochemical processing of DOC and the subsequent production of greenhouse gases had not been considered. Understanding of the rate of turnover of DOC in aquatic systems remains incomplete and further efforts are required to quantify the extent to which biogeochemical processes in aquatic systems are a source of $\mathrm{C}$ to the atmosphere.

Photochemical reactions in aquatic systems are induced by the absorption of solar radiation, particularly in the UV region of the spectrum, and preferentially affect aromatic, high-molecular-weight (HMW) molecules derived from allochthonous sources. Upon radiation, HMW DOC is converted to microbially available low-molecular-weight (LMW) carbon substrates (Opsahl and Benner, 1998; 
Sulzberger and Durisch-Kaiser, 2009). Photodegradation of $\mathrm{DOC}$ also results in the production of C-based gases, primarily $\mathrm{CO}_{2}$ and $\mathrm{CO}$ (Miller and Zepp, 1995; Stubbins et al., 2011). Whilst it is understood that input of photochemically labile terrigenous DOC can regulate $\mathrm{C}$ cycling in aquatic systems (Cory et al., 2014; Koehler et al., 2014), the significance of DOC photodegradation processes in these cycles remains poorly constrained over time and space (Franke et al., 2012; Moody et al., 2013). Due to low temperatures and short residence times limiting autochthonous (in situ) DOC production in headwater systems of northern peatlands, photochemical processing may be a proportionately more important process.

A key control on DOC concentrations in headwater systems is rainfall events which flush young, less degraded plant material within the catchment into streams (Austnes et al., 2010). Rainfall events have been shown to contribute significantly to annual $\mathrm{C}$ export from peatland headwater streams (Clark et al., 2007), yet the degree to which they replenish photolabile material within the aquatic environment is less certain. Stormflows in northern catchments have been associated with increased contribution of humic-like material (Fellman et al., 2009), suggesting that DOC photoreactivity may also increase during these events. Several studies have explored seasonal variation in intrinsic DOC photoreactivity in northern aquatic systems (Franke et al., 2012; Vachon et al., 2016), yet, to our knowledge, the contribution of rainfall events to the seasonal cycle of photolabile material has not been previously investigated.

Further uncertainty remains in understanding the variation in DOC photolability at different positions within a watershed (Franke et al., 2012). The increasing residence time of downstream aquatic systems, as headwater streams drain into rivers, lacustrine and marine environments, may mean that photo-processing becomes a more important control on overall $\mathrm{C}$ budgets with distance downstream. Conversely, the extent to which the material has already been degraded in the upstream aquatic environment may mean that further processing is limited (Vähätalo and Wetzel, 2008; Catalán et al., 2016). Investigating the susceptibility of DOC to photoprocessing in different types of aquatic environments will allow the overall contribution of photochemical processes to $\mathrm{C}$ cycling to be understood on a catchment scale.

The primary aim of this study was to assess temporal variation in the photochemical lability of DOC from two contrasting aquatic systems draining peatlands and to understand how this variation may impact aquatic $\mathrm{C}$ budgets. Controlled UV irradiation experiments were conducted on water samples collected from the two contrasting aquatic systems, one a stream and the other a reservoir. Water from both systems was sampled on a monthly basis over a 1-year period and also from the high-DOC stream system during two rainfall events to characterise short term variability in DOC concentration and composition. After experimental exposure, optical, spectroscopic and biogeochemical analyses of the water samples were conducted to explore DOC photoreactivity and the resultant production of $\mathrm{C}$ based gases. The results were used to test the following hypotheses:

- H1: both aquatic systems will exhibit seasonality with regards to the supply of photochemically labile DOC, with highest photolability detected in the winter due to limited processing in the aquatic environment.

- H2: photochemical degradation of DOC will be a more significant loss term of $\mathrm{C}$ in the high-DOC aquatic system.

- H3: rainfall events in the high-DOC system will replenish the supply of photolabile material.

\section{Methods}

\subsection{Study sites}

Water samples for the irradiation experiments were collected from two aquatic systems located in peatland catchments. The Black Burn $\left(55^{\circ} 47^{\prime} 34^{\prime \prime} \mathrm{N}, 3^{\circ} 14^{\prime} 35^{\prime \prime} \mathrm{W}\right.$; $254 \mathrm{~m}$ a.s.l.) is a small headwater stream draining Auchencorth Moss, an ombrotrophic peatland located in central Scotland covering $3.35 \mathrm{~km}^{2}$ (Billett et al., 2010). The stream is fed by a number of small tributaries from the surrounding peatland, part of which is used for peat extraction. Low-density sheep grazing is the primary land use within the catchment and vegetation comprises a Sphagnum base layer and hummocks of Deschampsia flexuosa and Eriophorum vaginatum, or Juncus effusus. In the upper catchment shrubs are present, including Calluna vulgaris, Erica tetralix and Vaccinium myrtillus (Dinsmore et al., 2010; Drewer et al., 2010).

The Black Burn stream hydrographic record is characterised by a steady base flow and rapid ("flashy") response to rainfall events which typically produce high flow accompanied by elevated DOC concentrations. Annual mean stream water DOC concentrations determined by weekly sampling over a 2-year period were high, at $28.4 \pm 1.07 \mathrm{mg} \mathrm{L}^{-1}$ (Dinsmore et al., 2013), with a marked seasonal pattern, characterised by low DOC in winter and high concentrations in summer. In this study, water samples were collected from an established sampling site where DOC concentrations have been recorded for $>9$ years as part of the Centre for Ecology \& Hydrology (CEH) Carbon Catchments project (https://www.ceh.ac.uk/our-science/projects/ ceh-carbon-catchments).

The other sampling site was Loch Katrine $\left(56^{\circ} 25^{\prime} 25^{\prime \prime} \mathrm{N}\right.$, $4^{\circ} 45^{\prime} 48^{\prime \prime} \mathrm{W} ; 118 \mathrm{~m}$ a.s.1.) in the Loch Lomond and Trossachs National Park, Scotland. Loch Katrine has a surface area of $8.9 \mathrm{~km}^{2}$ and is fed by $>80$ tributaries which predominantly drain a catchment of upland blanket bog. Loch water DOC concentrations have been recorded by the Scottish Environment Protection Agency (SEPA) at Ruinn Dubh Aird, a peninsula located at the south-eastern end of the loch, which was also selected as the sampling point for this study. DOC 
concentrations measured approximately six times a year from 2009-2014 were low at $3.68 \pm 0.56 \mathrm{mg} \mathrm{L}^{-1}$ (D. Frew, SEPA, personal communication, 2015).

\subsection{Sample collection}

Water was sampled monthly from both sites from May 2014 to May 2015 inclusive (13 samples over the study duration) to characterise seasonal variation in DOC concentration and composition. Samples were collected at $20 \mathrm{~cm}$ below the surface of the water in a screw top sterile clear glass bottle. Upon return to the laboratory, samples were stored in the dark at $4^{\circ} \mathrm{C}$ and exposed to experimental conditions within a week of collection. Additional water sampling to characterise the effect of rainfall events focused on the Black Burn head water system. Intensive stream water sampling was conducted during two rainfall events, one in winter (defined as 1 October to $31 \mathrm{March}$ ) and the other during the summer (1 April to 30 September) (Gordon et al., 2004). An automatic water sampler (Teledyne Isco, USA) was programmed to collect a composite $1 \mathrm{~L}$ sample of water from the Black Burn into separate polypropylene bottles every $60 \mathrm{~min}$ (comprising two $500 \mathrm{~mL}$ samples collected each $30 \mathrm{~min}$ ) throughout the rainfall events. Stream water sampling in the winter rainfall event was conducted from 11:00 on 9 December to 17:00 GMT on 10 December 2014, resulting in 31 samples across the event. Stream water sampling in the summer rainfall event started at 14:30 on 1 September and finished at 06:30 GMT on 2 September 2015, resulting in 17 samples. Water samples were transferred into glass bottles from the automatic water sampler for transport to the laboratory and irradiated within 5 days of collection.

Throughout the year of sampling, the Black Burn water depth was measured at $15 \mathrm{~min}$ intervals approximately $2 \mathrm{~km}$ downstream from the sampling site using a Level TROLL pressure transducer (In Situ Inc., USA) with atmospheric correction from a BaroTROLL sensor (In Situ Inc., USA) located above the water surface. Water depth readings from the pressure transducer were converted to discharge at the sampling site using rating curves $\left(R^{2}>0.90\right)$ based on flows measured by dilution gauging (Dinsmore et al., 2013). Equivalent hydrological data were not available for Loch Katrine.

\subsection{Sample preparation}

Prior to experiments, water samples were degassed under a vacuum pressure system for $20 \mathrm{~min}$ to remove dissolved gas from the water and then filtered using syringe-driven pore size $0.22 \mu \mathrm{m}$ MCE filters (Merck Millipore, UK) to reduce the effect of microbial activity. Then, $15 \mathrm{~mL}$ of filtered sample was immediately transferred into $21 \mathrm{~mL}$ quartz vials (Robson Scientific, UK), which were sealed with aluminium crimp tops and rubber butyl plugs (Chromacoal, UK). All samples were prepared at room temperature in oxygenated conditions.

\subsection{Irradiation experiments}

Experiments providing both UV-A and UV-B irradiation were conducted using UV313 lamps (Q-Panel Company, USA) covered with $125 \mu \mathrm{m}$ cellulose diacetate (A. Warne, UK) to exclude UV-C $(<280 \mathrm{~nm})$ and short-wavelength UVB $(<290 \mathrm{~nm})$. Lamps were mounted inside quartz tubing (Robson Scientific, UK) beneath the water surface in a water bath maintained at $16^{\circ} \mathrm{C}$ and vials were irradiated sideways while submerged. UV irradiance of the samples was modulated to remain constant throughout the $8 \mathrm{~h}$ exposure by measurement with an erythemally weighted UV-B broadband sensor with a dimmer (model PMA2102; Solar Light Inc., USA). The sensor was held beneath the water surface behind a quartz window of the same thickness as the vials. The UV exposure was calibrated with a double monochromator scanning spectroradiometer (Irradian ${ }^{\mathrm{TM}}$, UK), itself calibrated against a quartz halogen standard (FEL Lamp, F-1297) operated by the NERC Field Spectroscopy Facility, Edinburgh (http://fsf.nerc.ac.uk/). Total unweighted irradiance was $2.89 \mathrm{~W} \mathrm{~m}^{-2}$ in the UV-B, $4.63 \mathrm{~W} \mathrm{~m}^{-2}$ in the UV-A, and photosynthetically active radiation (PAR) was $0.92 \mathrm{~W} \mathrm{~m}^{-2}$ (Table 1; Fig. S1 in the Supplement). These conditions reflect twice the UV-B irradiance that could be expected over a cloudless summer day in the UK and a significant underestimation of summer time daily ambient UV-A and PAR. Weighting functions derived for a range of photochemical processes were applied to the spectral output (Table 1) and were determined to be within the range of global irradiance values. The time duration of the experiment $(8 \mathrm{~h})$ was selected to represent a conservative estimate of the exposure time of surface water during transit through a headwater peatland catchment to a marine outlet. Water temperatures of $\sim 16^{\circ} \mathrm{C}$ were measured in both field sites in May 2014 prior to commencement of the year-long sampling programme and was employed in the experiments to represent summer time conditions. Controls comprising quartz vials containing water samples and wrapped in aluminium foil to exclude radiation were kept in the water bath for the experiment duration, with four replicates of each of the UV-exposed and control samples.

To select water samples from the Black Burn for irradiation experiments, particulate organic carbon (POC) concentrations, $A_{254}$ values and E4 : E6 ratios were measured within $24 \mathrm{~h}$ in all samples (using the methods described below) and, from these results, eight stream water samples were selected from each rainfall event which represented the minimum, maximum and median values of these parameters (Table S1 in the Supplement).

\subsection{Analytical methods}

On each monthly sampling occasion the water dissolved oxygen (DO), conductivity, $\mathrm{pH}$ and temperature were measured on site with a handheld Hach HQd multimeter (Hach, USA). 
Table 1. Photosynthetically active radiation (PAR) and ultraviolet irradiances during $8 \mathrm{~h}$ exposures to Q-Panel UV313 fluorescent lamps filtered with $125 \mu \mathrm{m}$ cellulose diacetate.

\begin{tabular}{|c|c|c|c|c|c|c|c|}
\hline \multicolumn{8}{|c|}{ Irradiance $\mathrm{W} \mathrm{m}^{-2}$} \\
\hline $\begin{array}{l}\text { Total UV } \\
(280-400 \mathrm{~nm})\end{array}$ & $\begin{array}{l}\text { UV-A } \\
(315-400 \mathrm{~nm})\end{array}$ & $\begin{array}{l}\text { UV-B } \\
(280-315 \mathrm{~nm})\end{array}$ & $\begin{array}{l}\text { PAR } \\
(400-700 \mathrm{~nm})\end{array}$ & $\mathrm{CH}_{4}{ }^{\mathrm{a}}$ & GEN $(G)^{b}$ & $\mathrm{PG}^{\mathrm{c}}$ & $\mathrm{DNA}^{\mathrm{d}}$ \\
\hline 7.52 & 4.63 & 2.89 & 0.92 & 2.50 & 1.25 & 1.05 & 0.98 \\
\hline
\end{tabular}

Measured volumes of water samples were filtered within $24 \mathrm{~h}$ of collection through pre-ashed $\left(8 \mathrm{~h}\right.$ at $\left.450^{\circ} \mathrm{C}\right)$, pre-weighed Whatman GF/F $(0.7 \mu \mathrm{m}$ pore size) filter papers. POC was determined using loss on ignition, following the method of Ball (1964).

Following irradiation, partitioning of dissolved $\mathrm{C}$ gases from the liquid into the vial headspace was encouraged through use of a wrist action shaker for $30 \mathrm{~s}$. An Agilent gas chromatography (GC) system (Hewlett Packard 6890; Agilent Technologies, USA) equipped with an autosampler (HTA, Italy) and a flame ionisation detector (FID) held at $250{ }^{\circ} \mathrm{C}$ was used to analyse samples for headspace $\mathrm{CO}_{2}, \mathrm{CO}$ and $\mathrm{CH}_{4}$ concentration within $8 \mathrm{~h}$ of irradiation. Needle penetration depth was set to a standard depth and $1.5 \mathrm{~mL}$ of headspace sample was automatically injected into the sample loop. Analytical runs lasted for $10.5 \mathrm{~min}$ and the column carrier gas was $\mathrm{N}_{2}$ at a constant flow rate of $45 \mathrm{~mL} \mathrm{~min}^{-1} . \mathrm{CO}_{2}$ and $\mathrm{CO}$ measurements were made possible by a methaniser fitted between the column and FID. A standard seven-gas mixture (BOC Special Gases, UK) was used for daily detector calibration prior to sample analysis (detection limits: $\mathrm{CO}_{2} 78 \mathrm{ppm}$; $\mathrm{CO} 1.6 \mathrm{ppm} ; \mathrm{CH}_{4} 0.8 \mathrm{ppm}$ ). Dilutions of 50 and $75 \%$ were made from this standard using zero-grade $\mathrm{N}_{2}$ to produce a three-point calibration for each gas. Post-run peak analysis and integration were performed using Clarity software (DataApex, Czech Republic).

DOC and total carbon (TC) concentrations were measured using a PPM LABTOC analyser (Pollution and Process Monitoring Ltd, UK) in UV treatment and control samples after exposure. Dissolved inorganic carbon (DIC) was calculated as the difference between TC and DOC. UV-visible absorbance of UV treatment and control samples contained in $3.5 \mathrm{~mL}$ PLASTIBRAND ${ }^{\circledR}$ UV cuvettes with a path length of $10 \mathrm{~mm}$ was measured at room temperature between 200 and $800 \mathrm{~nm}$ at increments of $1 \mathrm{~nm}$ using a Jenway spectrophotometer (model 7315; Bibby Scientific, UK). Deionised water controls were used between each sample. Absorption coefficients $a_{\lambda}$ were calculated as

$a_{\lambda}=2.303 x\left(\frac{A \lambda}{L}\right)$, where $A$ is the absorbance at each wavelength and $L$ is the path length $(\mathrm{m})$ of the cuvette. Specific UV absorbance (SUVA $\left._{254}\right)$ values, a measure of DOC aromaticity, were determined by dividing the UV absorbance measured at $\lambda=$ $254 \mathrm{~nm}$ by the DOC concentration (Weishaar et al., 2003). E4 : E6 ratios were estimated using the absorbance values at 465 and $665 \mathrm{~nm}$, respectively (Peacock et al., 2014). Spectral slope $(S)$ was calculated using a nonlinear fit of an exponential function to the absorption spectrum in the ranges of 275-295 and $350-400 \mathrm{~nm}$, where $S$ is the slope fitting parameter. The spectral slope ratio $\left(S_{\mathrm{R}}\right)$ was calculated as the ratio of $S_{275-295}$ to $S_{350-400}$ (Helms et al., 2008; Spencer et al., 2009).

Fluorescence intensity in water samples filtered to $0.2 \mu \mathrm{m}$ was measured using a FluroMax-4 spectrofluorometer (Horiba Jobin Yvon Ltd., Japan). The instrument was programmed to scan across excitation wavelengths $200-400 \mathrm{~nm}$ (5 $\mathrm{nm}$ increments) and emission wavelengths $250-500 \mathrm{~nm}$ ( $2 \mathrm{~nm}$ increments) with a $1 \mathrm{~cm}$ path interval. Data were obtained at room temperature and were blank-corrected using deionised water. Intensity ratios derived using these data allow discrimination between different sources of DOC. Here, the fluorescence index (FI), $f_{450} / f_{500}$, the ratio of fluorescence intensity at the emission wavelength $450 \mathrm{~nm}$ to that at $500 \mathrm{~nm}$ at excitation wavelength $370 \mathrm{~nm}$, was calculated to help identify dissolved organic matter (DOM) source material. Values around 1.8 suggest autochthonous organic material, whereas values around 1.2 indicate terrestrially derived material (Cory and McKnight, 2005).

Lignin phenol concentrations in unirradiated Black Burn water samples were measured using the $\mathrm{CuO}$ oxidation method (Benner et al., 2005; Spencer et al., 2008). After filtration to $0.2 \mu \mathrm{m}, 45 \mathrm{~mL}$ of water sample was freeze-dried to produce lyophilised DOM, which was transferred to stainless steel pressure bombs with $1 \mathrm{~g}$ of $\mathrm{CuO}$ and $100 \mathrm{mg}$ of $\mathrm{Fe}\left(\mathrm{NH}_{4}\right)_{2}\left(\mathrm{SO}_{4}\right)_{2} \mathrm{H}_{2} \mathrm{O}$. Under anaerobic conditions, $8 \mathrm{~mL}$ of $\mathrm{NaOH}$ was added to the bombs before they were sealed. Samples were then oxidised at $155^{\circ} \mathrm{C}$ for $3 \mathrm{~h}$. Following oxidation, samples were acidified to $\mathrm{pH} 1$ with $\mathrm{H}_{2} \mathrm{SO}_{4}$, extracted with ethyl acetate three times, and then passed through $\mathrm{Na}_{2} \mathrm{SO}_{4}$ drying columns. Samples were dried using a flow of $\mathrm{N}_{2}$ and kept frozen prior to GC analysis. Af- 
ter redissolution in $200 \mu \mathrm{L}$ of pyridine, lignin phenols were derivatised with bis-trimethylsilyl trifluoromethyl acetamide (BSTFA) at $60^{\circ} \mathrm{C}$ for $30 \mathrm{~min}$ and quantified on a GC (Agilent 5890 MkII with twin FID). Specifically, a twin-column splitinjection method was used with Agilent DB1 and DB1701 (both $30 \mathrm{~m} \times 0.25 \mathrm{~mm}$ diameter $\times 0.25 \mu \mathrm{m}$ film thickness) flow being split in the injection liner with a twin-hole ferrule. Column flow was $1 \mathrm{~mL} \mathrm{~min}^{-1}$ with a split ratio of $20: 1$. The chromatographic conditions were $100^{\circ} \mathrm{C}$ held for $1.25 \mathrm{~min}$, followed by a heating rate of $4^{\circ} \mathrm{Cmin}^{-1}$ until $270^{\circ} \mathrm{C}$, then held for $15 \mathrm{~min}$.

Eleven lignin phenols were measured, including three $p$ hydroxybenzene phenols (P): $p$-hydroxybenzaldehyde, $p$ hydroxyacetophenone, $p$-hydroxybenzoic acid; three vanillyl phenols $(\mathrm{V})$ : vanillin, acetovanillone, vanillic acid; three syringyl phenols (S): syringaldehyde, acetosyringone, syringic acid; and two cinnamyl phenols $(\mathrm{C})$ : $p$-coumaric acid and ferulic acid. Blank controls, taken through the method from $\mathrm{CuO}$ oxidation onwards, were quantified and subtracted from sample concentrations. Quantification was achieved through use of cinnamic acid as an internal standard. In addition to total concentration of lignin phenols $\left(\Sigma_{11}\right)$ and carbon normalised yields $\left(\Lambda_{11}\right)$, the ratio of syringyl to vanillyl phenols (S / V), the ratio of cinnamyl to vanillyl (C / V) phenols, the ratio of $p$-hydroxybenzenes to vanillyl phenols $(\mathrm{P} / \mathrm{V})$ and the ratio of acids to aldehydes $\left(\mathrm{Ad} / \mathrm{Al}_{\mathrm{v}, \mathrm{S}}\right)$ were calculated to aid interpretation of the data. Lignin phenols for Loch Katrine samples were not measured due to insufficient production of lyophilised material using the stated method.

\subsection{Data analysis}

Data collected in the irradiation experiments were tested for normality using the Shapiro-Wilks test and were found to be normally distributed. Unpaired $t$ tests were conducted between irradiated and unirradiated samples to assess differences in spectral properties, DOC and DIC concentrations, lignin phenol concentration and gaseous production. Pearson correlation coefficients were used to test the potential role of DOC composition and site conditions in regulating photochemical lability, measured as total DOC loss, production of DIC and $\mathrm{C}$ gases $\left(\mathrm{CO}\right.$ and $\left.\mathrm{CO}_{2}\right)$ and change to $a_{254}$ and E4 : E6 ratios.

Carbon species DOC, $\mathrm{CO}_{2}$ and $\mathrm{CO}$ measured each month at the Black Burn and Loch Katrine were included in C mass budgets calculated for irradiated and unirradiated samples. By converting all data to $\mathrm{mg} \mathrm{L}^{-1}$, the difference in $\mathrm{C}$ budget between treatment and control samples could be determined (see Table S2 in the Supplement for example calculations). To obtain a standard error value for differences between irradiated and control samples, the mean control value was determined and subtracted from each of the irradiated replicates.

Photoreactivity ( $\mathrm{mg} \mathrm{C} \mathrm{mg} \mathrm{DOC}{ }^{-1}$ ) was determined as total change to $\mathrm{C}$ species (DOC, $\mathrm{CO}_{2}$ and $\mathrm{CO}$ ) upon irradiation normalised for initial DOC concentration. For the Loch Ka- trine samples, where minimal net DOC changes upon irradiation were observed in the sample aliquots, photoreactivity ( $\mathrm{mg} \mathrm{C} \mathrm{mg} \mathrm{DOC}{ }^{-1}$ ) is expressed as the sum of gaseous photoproduction $\left(\mathrm{CO}_{2}\right.$ and $\mathrm{CO}$ only) divided by the initial DOC concentration. This is to avoid production of negative photoreactivity values for Loch Katrine, which may have been explained in large part by the limited resolution of the PPM LabTOC instrument at very low DOC concentrations.

Correlation coefficients were calculated between intrinsic sample photoreactivity and lignin phenol data. The DurbinWatson statistic was used to test for the presence of autocorrelation in residuals of lignin phenol analyses of stream water samples collected during rainfall events and showed no correlation between the samples. Minitab v.16 (Minitab Inc., USA) was used for all statistical analyses.

\section{Results}

\subsection{Climate and water chemistry conditions at time of sampling}

Total rainfall measured at the European Monitoring and Evaluation Programme (EMEP) supersite at Auchencorth Moss (Tørseth et al., 2012) for the 13-month sampling period was $1015 \mathrm{~mm}$. It varied from lowest monthly values in September and April to the highest in October (Fig. 1a). The mean air temperature of the study period was $7.7^{\circ} \mathrm{C}$, similar to the 8 -year average of $7.6^{\circ} \mathrm{C}$, and reached a maximum of $27.6^{\circ} \mathrm{C}$ in July 2014 and a minimum of $-7.9^{\circ} \mathrm{C}$ in January 2015 .

At Comer meteorological station, located $10 \mathrm{~km}$ from the Loch Katrine sampling site, rainfall was considerably higher, totalling $2368 \mathrm{~mm}$ over the sampling period (Fig. 1b) (Met Office, 2012). Seasonal variation in rainfall was clear, with $>40 \%$ of rainfall falling from December to February. Air temperatures were higher than at the Black Burn, with a mean of $10.2^{\circ} \mathrm{C}$.

Water chemistry differed considerably between the two aquatic systems over the year-long sampling (Table 2). The water temperatures reflected the difference in air temperature between the sites, with higher mean values at Loch Katrine than at the Black Burn. Mean $\mathrm{pH}$ at the Black Burn was 5.4, compared to 6.7 at Loch Katrine. Conductivity was more variable at the Black Burn and was on average $53 \mu \mathrm{S} \mathrm{cm}^{-1}$ higher than at Loch Katrine, although values at both sites were low. POC concentrations at the Black Burn were over double those at Loch Katrine. FI values were slightly higher at the Black Burn, but at both sites were low and stable, indicative of terrestrially derived DOC material (Cory and McKnight, 2005).

DOC concentrations at the Black Burn ranged from 14.2 to $50.9 \mathrm{mg} \mathrm{L}^{-1}$ (Fig. 2) and showed a similar seasonal pattern as described in Dinsmore et al. (2013). Concentrations were lowest in late winter and highest in autumn, the latter 


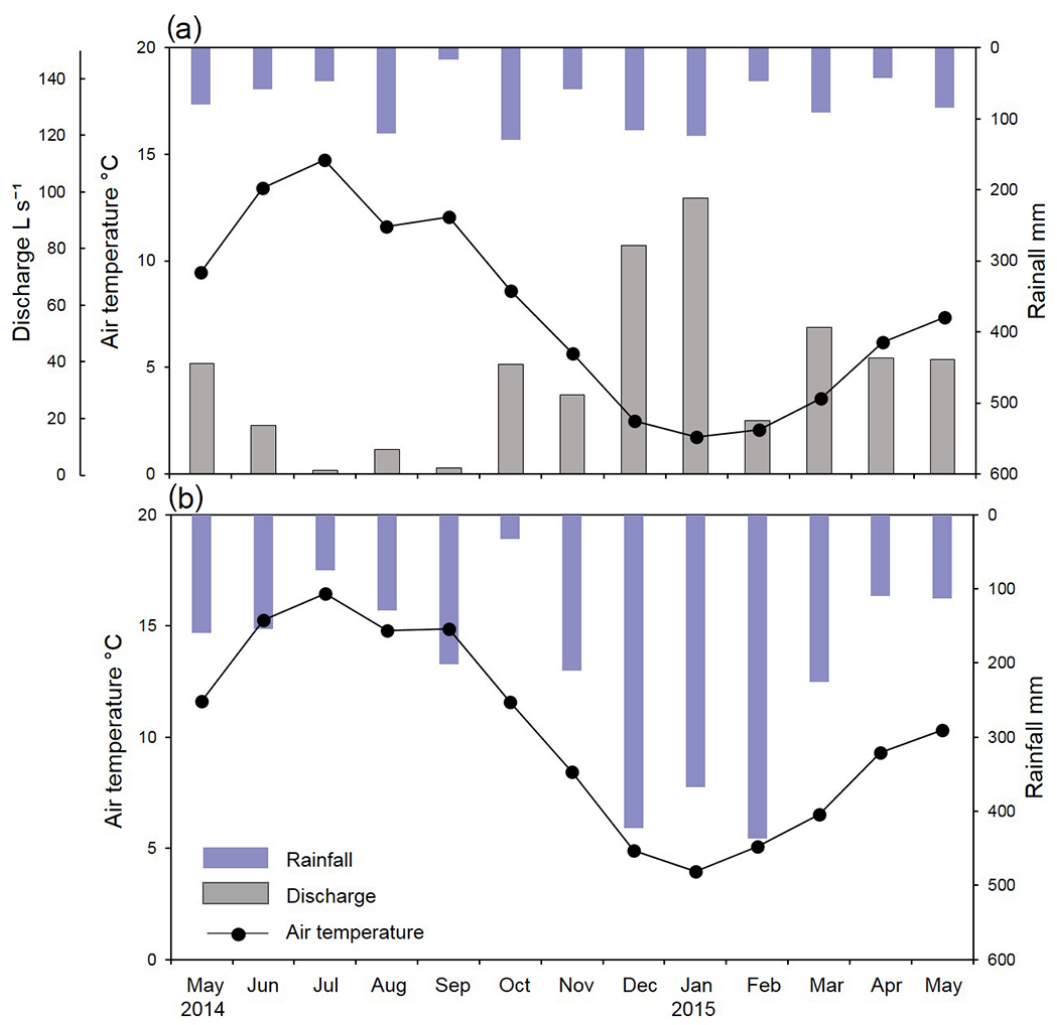

Figure 1. Mean monthly air temperature, total rainfall and mean discharge from May 2014 to May 2015 are shown for (a) Auchencorth Moss, with discharge of the Black Burn shown on the left-hand offset axis. Mean monthly air temperature and total rainfall are shown for the same period for Comer meteorological station, near (b) Loch Katrine. Note inverted right-hand $y$ axes.

Table 2. Mean water temperature and chemistry parameters including $\mathrm{pH}$, conductivity, $\mathrm{POC}$ concentrations, and fluorescence index FI values at the Black Burn and Loch Katrine $(n=13 \pm 1$ standard deviation).

\begin{tabular}{lrr}
\hline & Black Burn & Loch Katrine \\
\hline Water temperature ${ }^{\circ} \mathrm{C}$ & $8.3 \pm 4.5$ & $10.9 \pm 5.1$ \\
$\mathrm{pH}$ & $5.4 \pm 0.9$ & $6.7 \pm 0.3$ \\
Conductivity $\mu \mathrm{S} \mathrm{cm}^{-1}$ & $78.2 \pm 30.7$ & $25.2 \pm 4.0$ \\
${\text { POC } \mathrm{mg} \mathrm{L}^{-1}}$ & $5.8 \pm 2.8$ & $3.0 \pm 0.6$ \\
FI value & $1.2 \pm 0.1$ & $1.1 \pm 0.2$ \\
\hline
\end{tabular}

consistent with increased organic matter inputs to the stream from flushing of soils during autumn rainfall events.

At Loch Katrine, DOC concentrations were low and consistent, ranging from 3.1 to $5.8 \mathrm{mg} \mathrm{L}^{-1}$. Concentrations were lowest in spring and highest in summer. SUVA 254 values at the Black Burn were higher than at Loch Katrine, suggesting that the DOC pool was comprised of a greater percentage of aromatic material (Weishaar et al., 2003). The E4 : E6 ratio at the Black Burn varied considerably over the sampling period, ranging from 1.0 to 10.2. At Loch Katrine, the E4 : E6 ratios were lower and less variable, but these are a less meaningful parameter in the low DOC concentration Loch Katrine sam- ples due to minimal absorbance in wavelengths greater than $400 \mathrm{~nm}$.

\subsection{Optical changes in water samples upon irradiation}

Absorbance coefficients typically decreased upon irradiation of water samples relative to dark controls, with the strongest decrease occurring in the UV part of the spectrum at $\sim 300 \mathrm{~nm}$ (Fig. 3). Percentage loss of absorbance upon irradiation was $5 \%$ greater in water samples from the Black Burn compared to Loch Katrine samples when averaged across wavelengths $250-400 \mathrm{~nm}$. In the Black Burn, decreases in absorbance were greatest in the summer, whereas at Loch Katrine the decreases in absorbance were greater in the winter and spring.

Percentage values consistently $>100 \%$ (where UV exposed samples showed an increase in absorbance upon irradiation relative to dark control samples) were recorded for summer water samples from Loch Katrine. E4 : E6 ratios decreased by a mean of 1.52 in irradiated Black Burn water samples, indicating accumulation of increasingly humic material in the remaining DOC pool during UV exposure. At Loch Katrine, E4:E6 ratios decreased by a mean of 0.21 upon irradiation. 
(a)
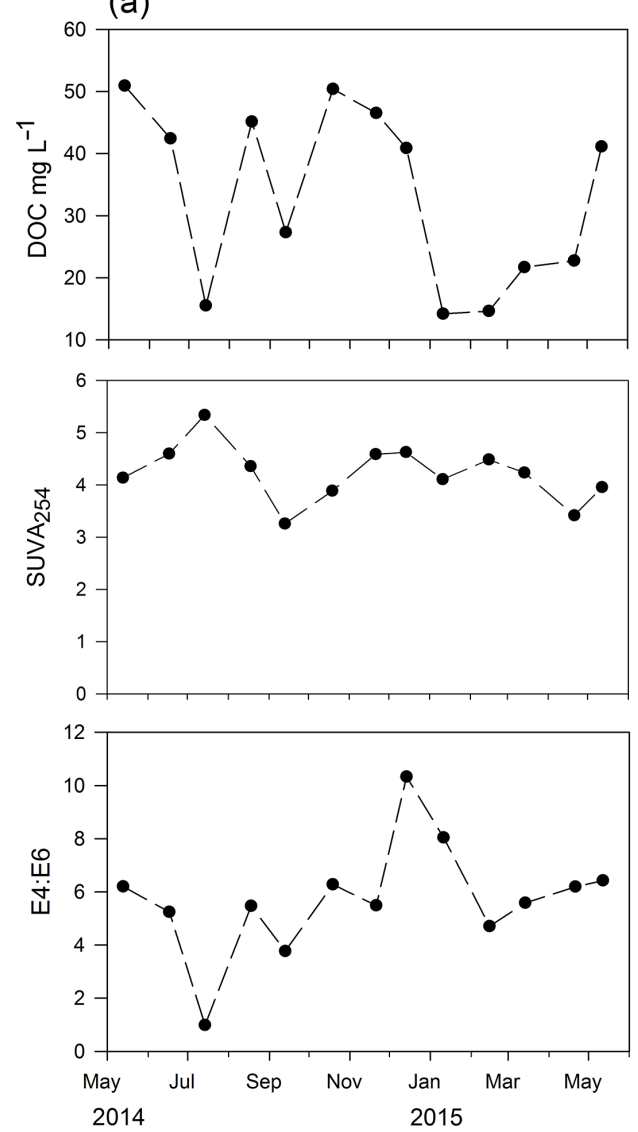

(b)
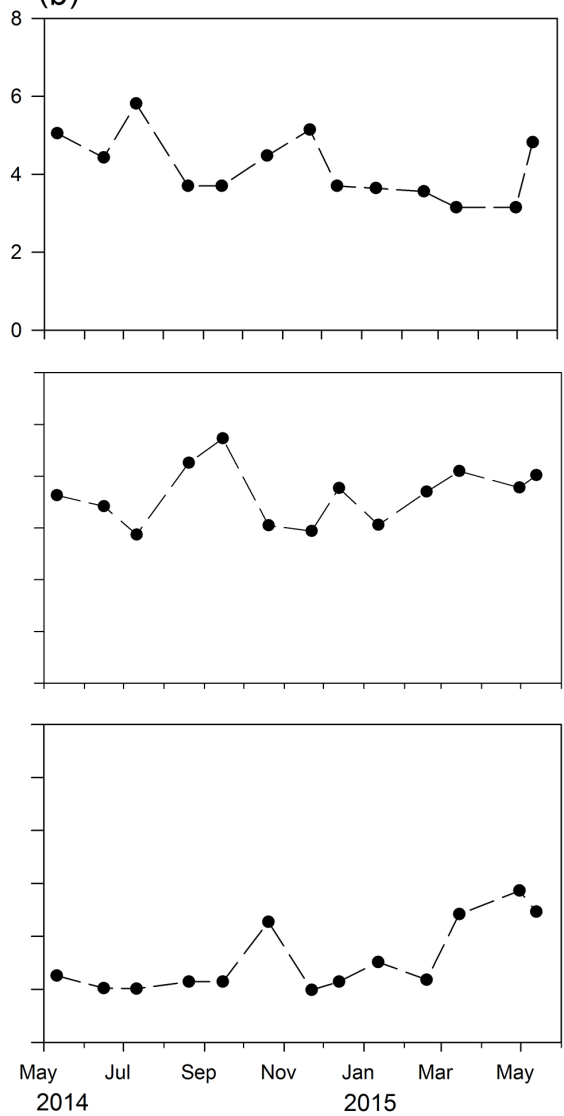

Figure 2. Time series at (a) the Black Burn and (b) Loch Katrine of DOC concentration and parameters for DOC quality: SUVA 254 and E4 : E6 from May 2014 to May 2015. Note different $y$ axis scales for DOC data.

\subsection{Carbon budget changes upon irradiation}

Typically, DOC concentrations in Black Burn water samples decreased after light exposure compared to unirradiated controls (Fig. 4a). Mean change in DOC in irradiated samples from the Black Burn for the whole sampling period was $-2.14 \mathrm{mg} \mathrm{CL}^{-1}$ (ranging from 0.06 to $-4.35 \mathrm{mg} \mathrm{CL}^{-1}$ for individual months). DOC decreased after irradiation in all Black Burn samples with the exception of September 2014, indicating a photolabile DOC pool for most of the year. In contrast, in water samples from Loch Katrine irradiationinduced DOC losses occurred in 5 of 13 samples and small gains were observed in 8 of 13 samples (Fig. 4b). Whilst these results should be interpreted with caution as small differences in DOC concentrations $\left(<0.5 \mathrm{mg} \mathrm{C} \mathrm{L}^{-1}\right)$ are below the instrument detection limit, they suggest that the DOC pool in Loch Katrine was largely recalcitrant to photochemical degradation.

Irradiation resulted in notable photoproduction of DIC, $\mathrm{CO}_{2}$ and $\mathrm{CO}$ from Black Burn samples. DIC concentration increased by a mean of $0.77 \mathrm{mg} \mathrm{CL}^{-1}$ for the whole sampling period, although production across the samples was highly variable between months. $\mathrm{CO}_{2}$ was the most abundant photoproduct and was produced at a mean rate of $1.2 \mathrm{mg} \mathrm{C} \mathrm{L}^{-1}$ across all monthly samples. At Loch Katrine, $\mathrm{CO}_{2}$ production was 2 orders of magnitude lower than in the Black Burn, produced at a mean rate of $0.06 \mathrm{mg} \mathrm{C} \mathrm{L}^{-1}$. In all monthly water samples from both sites $\mathrm{CO}$ concentrations increased in the irradiation experiments, with mean production rates of 0.07 and $0.01 \mathrm{mg} \mathrm{CL}^{-1}$ observed for Black Burn and Loch Katrine samples, respectively.

Carbon mass budgets for DOC loss and photoproduct accumulation (DIC, $\mathrm{CO}_{2}$ and $\mathrm{CO}$ ) in water samples were calculated for all the irradiation experiments. Budgets for all monthly water samples from the Black Burn were balanced to within $\pm 5.1 \%$ of the total measured $\mathrm{C}$ concentration. For Loch Katrine water samples, budgets were balanced to within $\pm 11 \%$. The lower accuracy of budget closure in the Loch Katrine samples is likely due to lower overall $\mathrm{C}$ concentrations, which are more susceptible to measurement error. $\mathrm{CH}_{4}$ was detected in all samples at very low levels, with mean concentrations of 0.63 and $0.57 \mu \mathrm{g} \mathrm{L}-1$ detected at the Black Burn and Loch Katrine, respectively, and thus were not included in the mass calculations. 
(a)

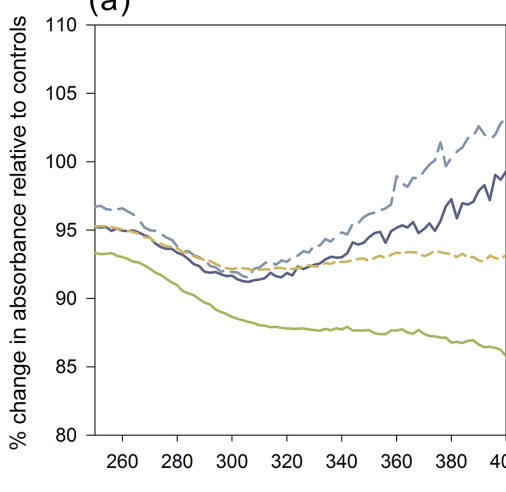

(b)

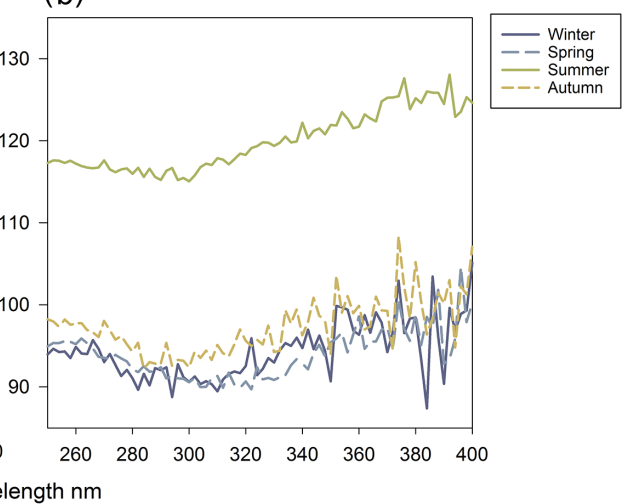

Figure 3. Change in absorbance upon irradiation expressed as a percentage of the unirradiated control samples from 250-400 nm at (a) Black Burn and (b) Loch Katrine. Summer is the mean of June, July and August values; autumn is the mean of September, October and November values; winter is the mean of December, January and February values; and spring is the mean of March, April and the combined mean of May 2014 and May 2015 values. Note different $y$ axis scales.

Intrinsic photoreactivity of $\mathrm{C}$ in the Black Burn ranged from 0.02 to $0.15 \mathrm{mg} \mathrm{Cmg} \mathrm{DOC}{ }^{-1}$ and was highest in August (Fig. 4a). Photoreactivity peaked again in November and remained elevated until January. Lowest sample photoreactivity was detected in September. At Loch Katrine, mean $\mathrm{C}$ photoreactivity was $0.017 \mathrm{mg} \mathrm{C} \mathrm{mg} \mathrm{DOC}^{-1}$, with a maximum of $0.025 \mathrm{mg} \mathrm{C} \mathrm{mg} \mathrm{DOC}^{-1}$ detected in November.

\subsection{Factors influencing carbon budget changes}

Factors influencing irradiation-induced changes to $\mathrm{C}$ species and spectral properties in Black Burn water samples were investigated using Pearson correlations (Table 3). Loss of DOC, absorbance at $254 \mathrm{~nm}$ and production of both $\mathrm{CO}_{2}$ and $\mathrm{CO}$ were significantly positively correlated with initial DOC concentration. Initial E4 : E6 ratios had positive coefficient values with all light-induced changes to the DOM pool, whilst FI values were all negative, although most of these correlations were not significant.

Of the meteorological and discharge variables investigated, air temperature and PAR were significantly negatively correlated with changes to E4 : E6 ratios. Total monthly rainfall had positive coefficient values with irradiation-induced changes to the DOM pool. Correlations between $\mathrm{C}$ species changes and discharge were less consistent, although mean monthly discharge was significantly positively correlated with changes to $\mathrm{E} 4$ : $\mathrm{E} 6$ ratios.

\subsection{Effect of rainfall events on carbon photo-processing in Black Burn water samples}

The Black Burn was sampled hourly during a winter rainfall event, with collection commencing $6 \mathrm{~h}$ before peak rainfall (Fig. 5a). Total rainfall during the event, which we define here as the water sampling period, was $19.6 \mathrm{~mm}$, with an hourly maximum of $3.3 \mathrm{~mm}$ and rainfall recorded in 22 of the 31 sampling hours. Stream discharge peaked at $391 \mathrm{~L} \mathrm{~s}^{-1}$ although a separate smaller peak of $266 \mathrm{~L} \mathrm{~s}^{-1}$ also occurred during the sampling period.

During the event, an initial dilution of stream DOC concentrations was followed by recovery to pre-event levels (Fig. 5a). DOC was most photoreactive at 06:00 GMT, with DOC concentration reduced after irradiation by $6.72 \mathrm{mg} \mathrm{L}^{-1}$. DOC loss in this sample was greater than at any time through the year-long study (Fig. 4a), even though the DOC concentration $\left(44.4 \mathrm{mg} \mathrm{L}^{-1}\right)$ was within the range of measured monthly concentrations. The greatest irradiation-induced increase in $\mathrm{CO}_{2}$ concentration $\left(2.25 \mathrm{mg} \mathrm{L}^{-1}\right)$ occurred in the first event sample at 11:00, collected prior to rainfall input. Photoreactivity was lowest at 12:00, and was similarly low in the sample collected at 17:00, which coincided with peak rainfall.

In the late summer rainfall event occurring at the end of an extended period of base flow in the Black Burn (Fig. S2 in the Supplement), $3.2 \mathrm{~mm}$ of rainfall was recorded with a maximum hourly total of $2.2 \mathrm{~mm}$. Samples were collected from 14:30 to $06: 30$, with rainfall only occurring between 16:30 and 18:30. Discharge remained low and relatively stable throughout the event, with a mean flow of $6.14 \mathrm{~L} \mathrm{~s}^{-1}$. Rainfall marginally diluted the stream DOC concentrations (Fig. 5b). Photo-induced changes were much smaller than in the winter event and maximum DOC losses were a factor of 2.5 lower than the mean DOC reduction observed in the Black Burn monthly water sample experiments (Fig. 4a). Photoreactivity was lowest in the initial sample collected at 14:30 prior to rainfall and coinciding with the highest discharge during the sampling period. Photoreactivity was highest in the 19:30 sample collected $3 \mathrm{~h}$ after peak rainfall. 


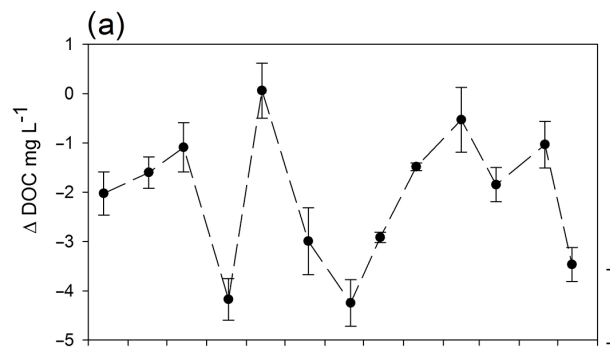

(b)
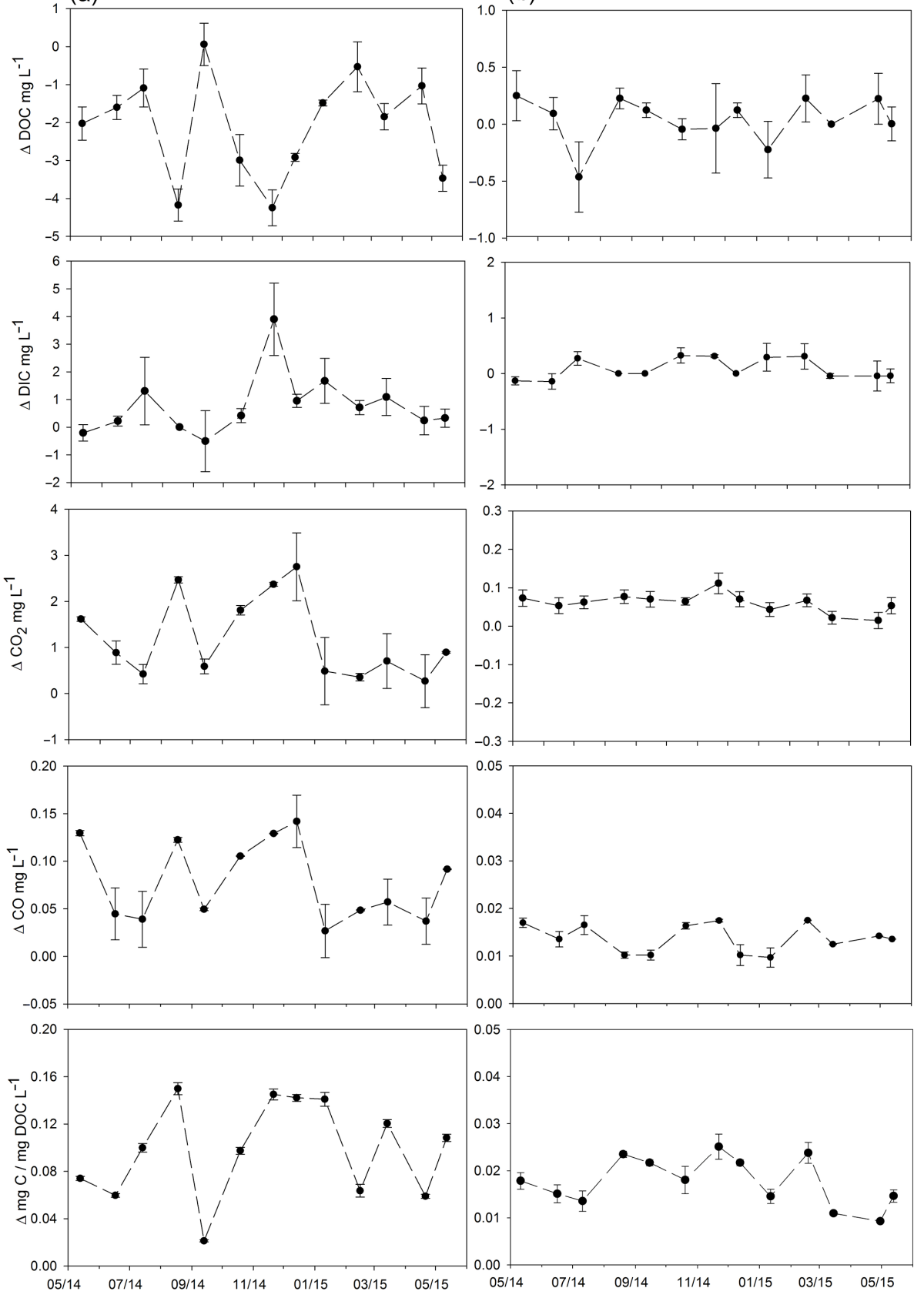

Figure 4. Irradiation-induced changes to carbon species DOC, DIC, $\mathrm{CO}_{2}$ and $\mathrm{CO}$ in monthly water samples from panel Black Burn (a) and Loch Katrine (b). DOC normalised changes to all C species changes (photoreactivity, quantified as explained in the text) are shown on the bottom row. Data represent the difference between the mean of irradiated and unirradiated control samples. Error bars show the standard error of the mean $(n=4)$. Note different $y$ axis scales for Black Burn and Loch Katrine water samples.

\subsection{Lignin phenol composition of Black Burn water samples}

To understand the effect of DOM composition on photolability, lignin phenols were measured in all the Black Burn monthly and rainfall events water samples prior to the irradiation experiments. Dissolved lignin concentrations ranged from 15.3 to $108 \mu \mathrm{g} \mathrm{L}^{-1}$ (mean $\left.=52.8 ; n=28\right)$ and were significantly positively correlated with sample DOC concentration (Pearson $=0.831 ; p<0.01$ ) (Fig. S3 in the Supplement). Carbon normalised yields were between 0.71 and $2.66 \mathrm{mg}(100 \mathrm{mg} \mathrm{OC})^{-1}$. The contribution of individual phenol groups to the lignin signature varied between monthly samples of the year-long study and the rainfall 
Table 3. Pearson correlation coefficients between irradiation-induced changes to aqueous carbon species and spectral properties, and water chemistry of Black Burn water samples from the year-long sampling campaign prior to irradiation and site conditions at Auchencorth Moss $(n=13)$.

\begin{tabular}{lrrrrrrrr}
\hline & $\Delta \mathrm{DOC}$ & $\Delta \mathrm{DIC}$ & $\Delta \mathrm{CO}_{2}$ & $\Delta \mathrm{CO}$ & $\Delta a_{254}$ & $\Delta a_{350}$ & $\Delta \mathrm{E} 4: \mathrm{E} 6$ & $\Delta S_{R}$ \\
\hline DOC & $0.708^{* *}$ & -0.074 & $0.773^{* *}$ & $0.824^{* *}$ & $0.766^{* *}$ & -0.168 & 0.095 & -0.547 \\
E4 :E6 & 0.366 & 0.049 & 0.463 & 0.434 & 0.183 & $-0.579^{*}$ & $0.770^{* *}$ & -0.157 \\
SUVA $_{254}$ & 0.228 & 0.460 & 0.232 & 0.129 & 0.231 & 0.157 & -0.098 & -0.059 \\
FI & -0.438 & -0.161 & -0.318 & -0.238 & -0.115 & 0.492 & -0.485 & -0.186 \\
Air temperature $^{\mathrm{a}}$ & -0.032 & -0.379 & -0.029 & -0.052 & 0.220 & 0.402 & $-0.571^{*}$ & -0.405 \\
Rainfall $^{\mathrm{b}}$ & $0.603^{*}$ & 0.061 & 0.537 & 0.445 & 0.365 & -0.389 & 0.492 & -0.226 \\
PAR $^{\mathrm{c}}$ & -0.161 & -0.459 & -0.380 & -0.267 & -0.224 & 0.054 & $-0.662^{*}$ & -0.489 \\
Discharge $^{\mathrm{d}}$ & 0.132 & 0.237 & 0.123 & 0.088 & -0.139 & -0.435 & $0.767^{* *}$ & -0.072 \\
\hline
\end{tabular}

${ }^{*} p<0.05 .{ }^{* *} p<0.01 .{ }^{\mathrm{a}}$ Mean monthly air temperature. ${ }^{\mathrm{b}}$ Total monthly rainfall $(\mathrm{mm}){ }^{\mathrm{c}}$ Mean monthly PAR $\left(\mu \mathrm{mol} \mathrm{m}{ }^{-1} \mathrm{~s}^{-1}\right)$.

d Mean monthly discharge $\left(\mathrm{L} \mathrm{s}^{-1}\right)$.

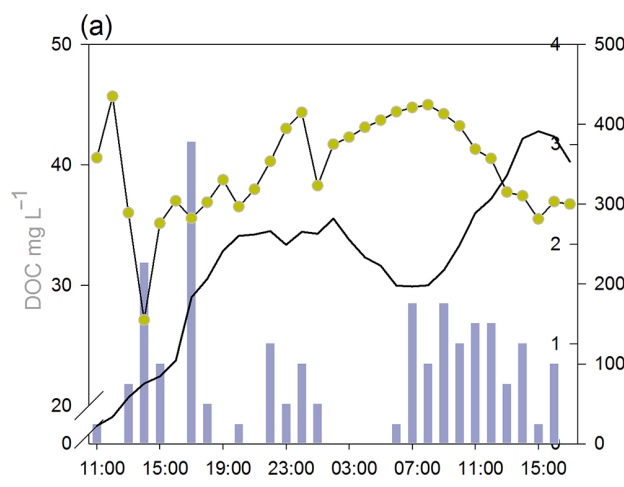

(b)

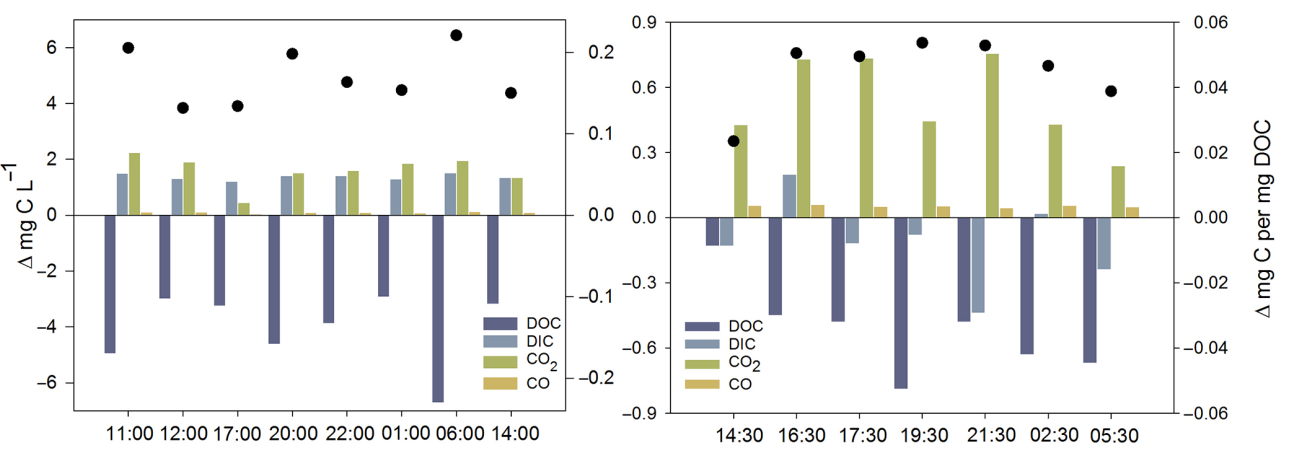

Figure 5. Rainfall events sampled on 9-10 December 2014 (a) and on 1-2 September 2015 (b). Row one shows a time series of hourly rainfall, discharge and DOC concentrations for each event. Row two shows photo-induced $\mathrm{C}$ pool changes of irradiated samples expressed as a total change value per $\mathrm{C}$ species in vertical bars (left $y$ axis) and as a DOC normalised value in dots (right $y$ axis). Data represent the difference between the mean of irradiated and unirradiated control samples $(n=4)$. Note different $x$ and $y$ axis scales.

events (Fig. 6). In the monthly samples, the P phenols were most abundant, followed by V phenols (Fig. 6a). Samples in the winter rainfall event contained higher and more variable mean yields for each phenol group, with $S$ phenols most abundant, followed by $\mathrm{V}$ phenols and $\mathrm{P}$ phenols.

Overall yields were significantly lower (one-way ANOVA, $p<0.01)$ during the summer rainfall event. As in the yearlong samples, $\mathrm{P}$ phenols were the most abundant, followed by $\mathrm{S}$ phenols and $\mathrm{V}$ phenols. Across all three sampling regimes, the contribution of $\mathrm{C}$ phenols to the overall lignin signature was smallest.

$\mathrm{P}: \mathrm{V}$ ratios, an indication of Sphagnum-derived DOC (see Sect. 4.2), ranged from 0.83 to 1.69 across all samples, indicating significant temporal variability in DOM source material. Photoreactivity was significantly negatively correlated with $\mathrm{P}: \mathrm{V}$ ratios when all samples were combined in a correlation analysis $(-0.523 ; p<0.01)$ (Fig. 7a). This suggests that the relative abundance of $\mathrm{P}$ versus $\mathrm{V}$ phenols contributed considerably to sample photoreactivity. The lowest $\mathrm{P}: \mathrm{V}$ ra- 

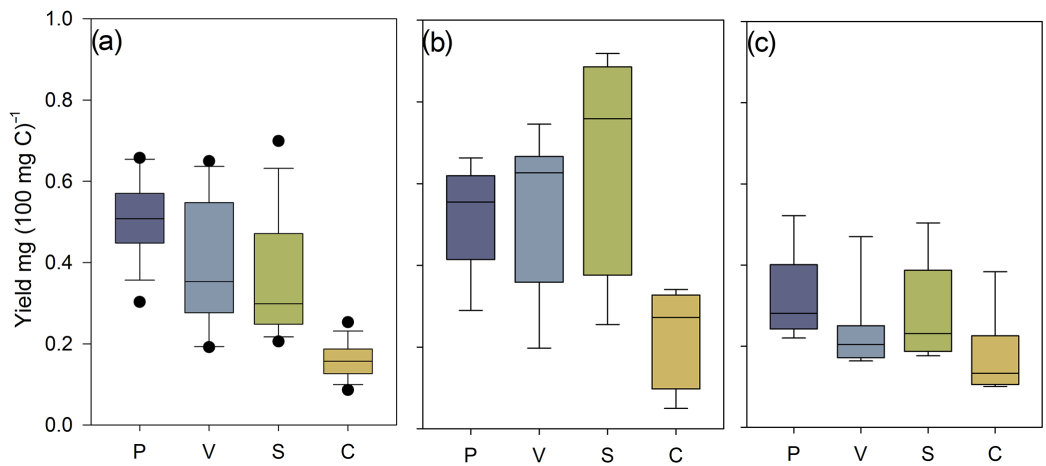

Figure 6. Box plots of carbon-normalised yields of phenols groups for Black Burn water samples collected (a) monthly in the year-long study $(n=13)$, (b) during the winter rainfall event $(n=8)$ and (c) during the summer rainfall event $(n=7)$. P: $p$-hydroxyl; V: vanillyl; S: syringyl; and C: cinnamyl. The box spans from the first quartile to the third quartile, with the line showing the median value. Whiskers show the minimum and maximum values, with dots representing outlying values.
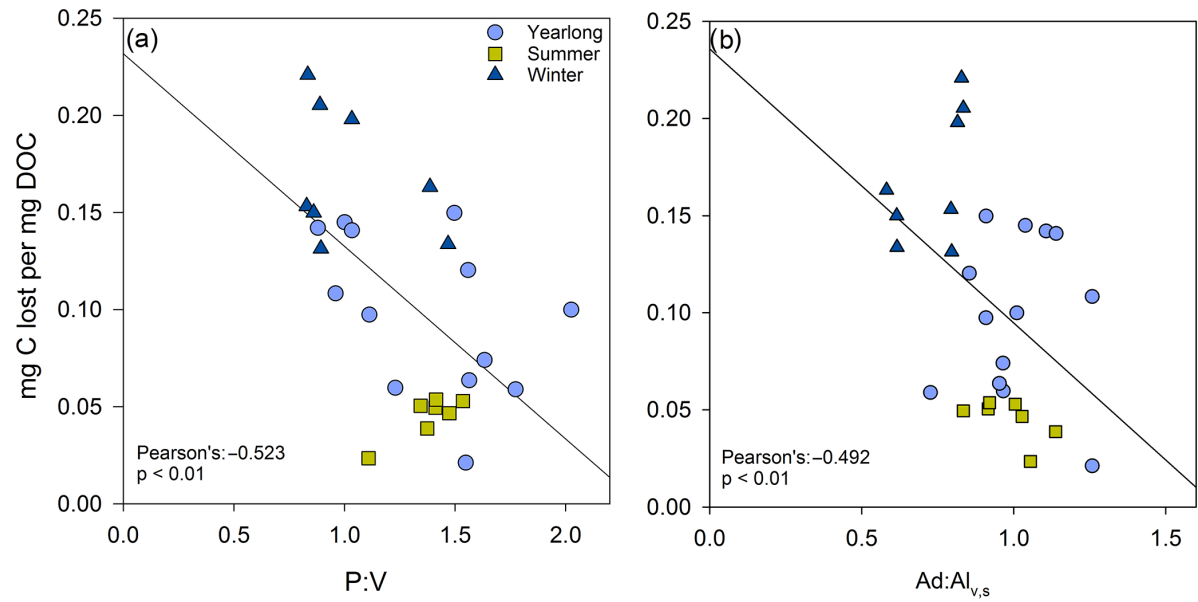

Figure 7. Pearson correlation between mg DOC lost upon irradiation per mg DOC and (a) $\mathrm{P}: \mathrm{V}$ ratios and (b) $\mathrm{Ad}: \mathrm{Al}_{\mathrm{V}, \mathrm{s}}(\mathrm{derived}$ from acids and aldehydes from vanillyl and syringyl phenol groups) ratios in all Black Burn water samples analysed ( $n=28)$. Lines of best fit for all water samples are also shown. The monthly samples in the year-long study and the winter and summer rainfall event samples are indicated.

tios were in winter rainfall event samples, where photoreactivity was highest.

Ad: $\mathrm{Al}_{\mathrm{V}, \mathrm{s}}$ ratios, which are an indicator of sample degradation, ranged from 0.58 to 1.26 , towards the lower end of reported values in the literature (Winterfeld et al., 2015). Photoreactivity was also significantly negatively correlated with $\mathrm{Ad}: \mathrm{Al}$ ratios $(-0.492 ; p<0.01)$ (Fig. $7 \mathrm{~b})$ and again lower ratios typically occurred in winter rainfall event samples.

\section{Discussion}

\subsection{Peatlands as a source of photochemically labile DOC}

Photo-processing resulted in considerable DOC loss from water samples from the Black Burn. Mean DOC loss in the $8 \mathrm{~h}$ irradiation experiments conducted on the monthly water samples was $7 \%$ relative to initial concentrations. Per- centage DOC losses determined here are similar to those reported from irradiation experiments conducted over similar timescales using stream water draining a boreal watershed (3-10\% DOC loss over 10 h; Franke et al., 2012 and $11 \%$ TOC loss over 19 h; Köhler et al., 2002). However, photochemical processes are dependent on the spectral composition of irradiation sources and direct comparison of percentage loss rates in this study with those of other experimental studies using different lamp types or ambient sunlight is not possible.

The irradiation source used in this study was selected as UV is the most effective source of radiation in producing photochemical effects (Häder et al., 2007; Zepp et al., 2007). The UV313 lamps provided both UV-B and UV-A exposures (2.89 and $4.63 \mathrm{~W} \mathrm{~m}^{-2}$ respectively), which were an appropriate UV-B exposure but a lower proportion of UV-A and visible wavelengths than ambient sunlight. Cellulose diacetate filters removed wavelengths $<290 \mathrm{~nm}$, which are absent in 
sunlight, but lamp outputs used in the irradiation experiments are not directly comparable to the solar spectrum. Consequently, the magnitude of photo-processing determined in this study allows relative comparison of temporal changes and between our sites but does not provide an accurate value of ambient photo-processing.

Photochemical transformations were low in the Loch Katrine samples, with minimal losses to the DOC pool $(0.43 \%$; mean from year-long study). Whilst our sites were not located within the same watershed, it seems likely that position within the catchment plays a role in determining the photolability of DOC. The Black Burn headwater stream at Auchencorth Moss receives fresh inputs of DOC from the surrounding peatland catchment and material has less time for solar irradiation exposure in the water column relative to the DOC in the reservoir system. DOC losses may occur in Loch Katrine soon after water entry into the loch but, due to long water residence times, DOC may have become recalcitrant to photo-processing by the time of sample collection. Catalán et al. (2016) observed a negative relationship between organic carbon decay and water retention time, resulting in decreased organic carbon reactivity along the continuum of inland waters. SUVA 254 data suggest that DOC in Loch Katrine samples was less aromatic than in the Black Burn (Table 2), with values indicating an approximate humic content of $30 \%$ based on the findings of Weishaar et al. (2003). As humic molecules are more labile to photo-processing, irradiation had a greater effect on the stream samples relative to the reservoir samples.

Strong seasonal fluctuations in DOC concentration and composition occurred in the Black Burn, in agreement with patterns observed in the same system by Dinsmore et al. (2013). DOC concentrations were highest in the late autumn, consistent with a flushing effect whereby soil organic material produced over the summer is mobilised and delivered to aquatic environments by more intense rainfall after a prolonged, relatively dry period (Fenner et al., 2005). Positive correlation between the irradiation-induced change in the E4 : E6 ratio and mean monthly discharge suggest that hydrological conditions in the month prior to sampling significantly influence the reactivity of the sample, with high flow delivering more reactive carbon to the stream. Change in the E4 : E6 ratio correlated significantly with several other variables; however, spectral dependence of absorption photobleaching depends on the spectral distribution of the irradiation source (Del Vecchio and Blough, 2002; Tzortziou et al., 2007). UVB-313 exposure may have produced a distinctly different absorption difference spectrum than ambient irradiance, though there is a lack of literature to test this assertion. Hence, whilst the correlations are significant and can be explained theoretically, they should be interpreted with caution.

Overall the magnitude of photo-induced $\mathrm{C}$ losses was significantly positively correlated with DOC concentration in the year-long Black Burn dataset. However, despite low DOC concentrations, photoreactivity remained elevated in January.
This suggests that even when lower DOC concentrations are detected in aquatic systems, the DOC may be intrinsically more photoreactive due to its aromatic content and minimal light exposure history.

Lowest DOC concentrations were observed in the late winter and early spring, due to depletion of soil organic $\mathrm{C}$ within the catchment by autumn and winter rainfall events. Low rainfall inputs limit the recharge of fresh, photolabile material to the stream and may account for the reduction in DOC photoreactivity detected in September. Furthermore, due to longer residence time in the water column, these samples may have already been degraded by natural light. A previous study at the Black Burn reported ${ }^{13} \mathrm{C}$ enrichment of stream water DOC in September, consistent with increased in-stream processing at this time of year (Leith et al., 2014). Reductions in intrinsic DOC photolability during summer have similarly been reported in northern lakes (Vachon et al., 2016) and a boreal watershed (Franke et al., 2012). Another minimum in photoreactivity occurred in April, when SUVA $_{254}$ data indicate decreased contribution of aromatic material to $\mathrm{C}$ within the stream. Although algal abundance was not measured during this study, production of DOC from such sources would account for the reduction in photolability (Nguyen et al., 2005).

Absorbance increased during irradiation of Loch Katrine samples in summer. A possible explanation for increased absorbance in the irradiated water samples is the formation of an iron (Fe)-DOC complex, since the reaction kinetics of Fe-DOC complexes are directly affected by light exposure (Maranger and Pullin, 2003). Whilst Fe concentrations were not measured in this study, in a SEPA bimonthly measurement campaign (2009-2013) at Loch Katrine peak Fe concentrations in August of up to $0.50 \mathrm{mg} \mathrm{L}^{-1}$ were detected, corresponding to the time of year when we found increased absorbance in irradiated water samples. As the dataset does not cover the sampling period, the role of Fe-DOC complexes in producing the observed effect cannot be directly determined; however the role of micronutrients in peatland aquatic $\mathrm{C}$ cycling should be further investigated.

Prior filtration of samples to $0.22 \mu \mathrm{m}$ means that the anomalous absorbance increases are unlikely to be the result of microbial DOC production. However, this cannot be entirely discounted as some bacteria can pass through $0.22 \mu \mathrm{m}$ filters and lacustrine freshwater bacteria colonies are seasonally variable, which may explain why the effect was only observed in summer (Kent et al., 2004; Fortunato et al., 2012). In order to determine microbial effects in the samples, stable $\mathrm{C}$ isotope $\left(\delta^{13} \mathrm{C}\right)$ data could be used as it can distinguish microbial activity from photochemical effects due to preferential fractionation of DOC fractions of different molecular weights for each respective process (Opsahl and Zepp, 2001). 


\subsection{Importance of rainfall events in mobilising photolabile material}

Dissolved lignin phenol composition indicates that different sources of plant material were mobilised as a result of rainfall in the Auchencorth Moss catchment. High P: V ratios have been used as an indicator of peatland inputs to aquatic systems, as Sphagnum-derived organic acids typical of peatlands are converted into $\mathrm{P}$ phenols during lignin extraction (Winterfeld et al., 2015; Fichot et al., 2016). Typically $\mathrm{P}$ phenols constituted the largest contribution to the total lignin concentration of the measured phenols, consistent with Sphagnum inputs. However, during the winter rainfall event where stream discharge was considerably higher than the year-long mean value, the largest contribution to total lignin concentration was from $\mathrm{S}$ and $\mathrm{V}$ phenols (Fig. 6). The former are reported to be the most photolabile phenol (Opsahl and Benner, 1998; Benner and Kaiser, 2011) and are unique to woody angiosperms. This suggests that hydrological pathways within the catchment were activated upon rainfall, causing DOC release from soil profiles associated with angiosperm plant material. Potential sources within the Auchencorth upper catchment are Calluna vulgaris, Erica tetralix and Vaccinium myrtillus. Further evidence of the operation of variable source areas in the catchment was the observation of delayed input of water, containing high $\mathrm{CO}_{2}$ concentrations, from the deep peat area in the upper catchment at Auchencorth Moss during a storm event (Dinsmore and Billett, 2008). Low P : V values and high lignin concentrations have been reported during peak flow in Arctic rivers, and the reverse during base flow (Amon et al., 2012). As samples with low P: V values were typically more photoreactive (Fig. 7a), our data indicate that rainfall events are important in mobilising photolabile material from this catchment.

Elevated $\mathrm{Ad}: \mathrm{Al}_{\mathrm{V}, \mathrm{S}}$ ratios have previously been interpreted as indicators of decomposition of organic matter resulting from preferential degradation of aldehydes relative to acids (Spencer et al., 2009; Lu et al., 2016). In the Black Burn water samples, lowest ratios were measured in the winter rainfall event. This implies that DOC mobilised during rainfall is less degraded relative to base flow DOC, in agreement with previous studies of peatland high-flow events which detected increased contribution of near surface flow and younger DOC (Clark et al., 2008). The form of the degradation, either microbial or photochemical, cannot be distinguished using these data. However, based on the higher measured photoreactivity of samples with lower ratios (Fig. 7b), light exposure history may be one of the key moderators of $\mathrm{Ad}: \mathrm{Al}_{\mathrm{V}, \mathrm{s}}$ ratios in the Black Burn. High-flow events release fresh DOC from soils derived from recent plant material and may have significant implications for $\mathrm{C}$ processing rates in streams as they are recharged with labile material (Lapierre et al., 2013).

Whilst the samples collected during the winter rainfall event were clearly distinct in composition relative to samples from the year-long study, the summer rainfall event sam- ples had similar $\mathrm{P}: \mathrm{V}$ and $\mathrm{Ad}: \mathrm{Al}_{\mathrm{V}, \mathrm{s}}$ ratios, but significantly lower photoreactivity and overall lignin yields (Figs. 5b, 6c, 7 ). This could be attributed to the timing of sample collection in early September at the end of summer, where considerable degradation may have already occurred across all phenol groups so that the DOC pool remaining was more recalcitrant to further photo-processing. Discharge data indicate that there was no discernible flushing effect during the summer rainfall event, with slight decreases in DOC concentration attributed to dilution of the stream water by direct rainfall inputs or overland flow. The abundance of $\mathrm{P}$ phenols, which have been determined as the least photoreactive phenol (Benner and Kaiser, 2011), within the samples suggests that passive transfer of DOC from the riparian zone, which is dominated by Sphagnum and Juncus vegetation, to the stream was the dominant mode of stream DOC recharge at this time of year (Jeanneau et al., 2015). The summer rainfall event samples were notably depleted in $\mathrm{V}$ phenols, suggesting that these phenols exert an important control on sample photoreactivity in addition to $\mathrm{S}$ phenols.

\subsection{Implications for photochemical turnover of DOC in aquatic systems}

Our $8 \mathrm{~h}$ irradiation experiments found $7 \%$ of DOC to be labile to photo-processing, with conversion to $\mathrm{CO}_{2}$ as the main loss pathway. Mass budget calculations for Black Burn water samples show that a mean of $\sim 46 \%$ of DOC loss in the irradiation experiments was accounted for by production of $\mathrm{CO}_{2}$. Dinsmore et al. (2010) estimate that $108 \pm 62.7 \mathrm{~kg} \mathrm{DOC} \mathrm{year}^{-1}$ is exported to the Black Burn from the Auchencorth Moss catchment. Given the significant volume of DOC produced by the catchment, in-stream photo-processing may be an important term in carbon budgets of peatland draining aquatic systems and may contribute to the high $\mathrm{CO}_{2}$ efflux reported from these systems (Billett et al., 2015). However, determining the volume of material photo-processed both in the stream and in downstream environments relies upon a range of unquantified factors, including optical depth and mixing processes in downstream aquatic environments which are generally poorly understood in relation to photochemical DOC processing.

Due to the effects of bank shading and short transit time of water within the immediate catchment, light-driven instream DOC processing is unlikely to be significant. The river continuum concept suggests that increased DOC processing will occur further downstream, where the channel widens (Vannote et al., 1980), and will be partly controlled by the stream water mean transit time (McGuire and McDonnell, 2006; McDonnell et al., 2010). Based on mean velocity ( $\left.\sim 0.58 \mathrm{~m} \mathrm{~s}^{-1}\right)$ of a larger nearby river (Ledger, 1981), we estimate a mean water transit time of $\sim 19 \mathrm{~h}$ from the Black Burn at Auchencorth Moss to its coastal outlet $34 \mathrm{~km}$ downstream, considerably longer than the exposure time in our experiments. However, in a study of first- to fourth-order 
streams in Sweden no significant change to DOM composition as stream order increased was detected and this was partly attributed to short transit times $(<2$ days) restricting DOC processing (Kothawala et al., 2015). Peatland-derived $\mathrm{C}$ in this study is clearly photoreactive, but limited time for in-stream processing may render photo-processing unimportant in the $\mathrm{C}$ budgets of some freshwater systems.

Recent studies have determined hotspots of DOC processing within peatland draining systems, which include mixing zones of freshwaters with different $\mathrm{pH}$, conductivity and metal concentrations (Palmer et al., 2015; Jones et al., 2015). In the context of this study, measuring DOC processing at the confluence of the Black Burn, which largely drains peatland, and the River North Esk, which drains a catchment of mixed land use including natural and plantation forestry, $4 \mathrm{~km}$ downstream of the point from which our samples were collected would provide a logical starting point for quantifying in situ DOC turnover.

Determining the $\mathrm{C}$ cycling implications of this study is further complicated as the most photoreactive material was recorded during a heavy winter rainfall event. The potential for photochemical transformation of DOC within the freshwater aquatic environment would have been limited due to low light availability, extensive cloud cover and decreased stream water transit times associated with the event. During the year-long study period, 12 rainfall events occurred which resulted in similar flow conditions in the Black Burn (stream discharge exceeding $250 \mathrm{~L} \mathrm{~s}^{-1}$ ), with a maximum discharge of $2059 \mathrm{~L} \mathrm{~s}^{-1}$ in a late winter storm. Of these highflow events, 11 occurred during winter and 1 in summer and hence, whilst large quantities of photoreactive material may have been mobilised during heavy rainfall, the likelihood of in-stream processing would remain small. Increases in precipitation, with more frequent and intense rainfall events, are expected with climate change (Capell et al., 2013; IPCC, 2014) with heavier summer downpours predicted in the UK (Kendon et al., 2014). Thus, although the contribution of rainfall events to photochemically induced $\mathrm{C}$ cycling in this study is likely to be minimal, they could become more significant if heavy rainfall events occur more frequently in summer.

Data availability. Data will be made available through the Environmental Information Data Centre (EIDC), a Natural Environment Research Council data centre hosted by the Centre for Ecology \& Hydrology (CEH), UK (http://eidc.ceh.ac.uk/).

\section{The Supplement related to this article is available online at doi:10.5194/bg-14-1793-2017-supplement.}

Author contributions. Amy E. Pickard collected field samples and undertook laboratory experiments, data analysis and writing of the paper. Kate V. Heal, Andrew R. McLeod and Kerry J. Dinsmore provided guidance on the scope and design of the project, and contributed to the editing of the manuscript.

Competing interests. The authors declare that they have no conflict of interest.

Acknowledgements. This work was funded by a Natural Environment Research Council (NERC) PhD studentship (NE/K500835/1). Further support was provided by a Moss PhD scholarship courtesy of Derek and Maureen Moss. The Irradian ${ }^{\mathrm{TM}}$ spectroradiometer used in this study was calibrated by Chris McLellan at the NERC Field Spectroscopy Facility. We thank Stephen Mowbray for his assistance with lignin phenol analyses and Andrew Addison for his contribution to fieldwork. We also thank Tony Dickinson and Jim Donnelly at the University of Central Lancashire for use of a Horiba FluroMax-4 spectrofluorometer.

Edited by: M. Tzortziou

Reviewed by: P. Neale and one anonymous referee

\section{References}

Amon, R. M. W., Rinehart, A. J., Duan, S., Louchouarn, P., Prokushkin, A., Guggenberger, G., Bauch, D., Stedmon, C., Raymond, P. A., Holmes, R. M., McClelland, J. W., Peterson, B. J., Walker, S. A., and Zhulidov, A. V.: Dissolved organic matter sources in large Arctic rivers, Geochim. Cosmochim. Ac., 94, 217-237, doi:10.1016/j.gca.2012.07.015, 2012.

Austnes, K., Evans, C. D., Eliot-Laize, C., Naden, P. S., and Old, G. H.: Effects of storm events on mobilisation and in-stream processing of dissolved organic matter (DOM) in a Welsh peatland catchment, Biogeochemistry, 99, 157-173, doi:10.1007/s10533009-9399-4, 2010.

Ball, D. F.: Loss-on-ignition as an estimate of organic matter and organic carbon in non-calcareous soils, J. Soil Sci., 15, 84-92, doi:10.1111/j.1365-2389.1964.tb00247.x, 1964.

Benner, R. and Kaiser, K.: Biological and photochemical transformations of amino acids and lignin phenols in riverine dissolved organic matter, Biogeochemistry, 102, 209-222, doi:10.1007/s10533-010-9435-4, 2011.

Benner, R., Louchouarn, P., and Amon, R. M. W.: Terrigenous dissolved organic matter in the Arctic Ocean and its transport to surface and deep waters of the North Atlantic, Global Biogeochem. Cy., 19, 1-11, doi:10.1029/2004GB002398, 2005.

Billett, M. F., Charman, D. J., Clark, J. M., Evans, C. D., Evans, M. G., Ostle, N. J., Worrall, F., Burden, A., Dinsmore, K. J., Jones, T., McNamara, N. P., Parry, L., Rowson, J. G., and Rose, R.: Carbon balance of UK peatlands: current state of knowledge and future research challenges, Clim. Res., 45, 13-29, doi:10.3354/cr00903, 2010.

Billett, M. F., Dinsmore, K. J., and Garnett, M. H.: Should aquatic $\mathrm{CO}_{2}$ evasion be included in contemporary carbon budgets for peatland ecosystems?, Ecoystems, 18, 471-480, 2015.

Capell, R., Tetzlaff, D., and Soulsby, C.: Will catchment characteristics moderate the projected effects of climate change on flow 
regimes in the Scottish Highlands?, Hydrol. Process., 27, 687699, doi:10.1002/hyp.9626, 2013.

Catalán, N., Marcé, R., Kothawala, D. N., and Tranvik, L. J.: Organic carbon decomposition rates controlled by water retention time across inland waters, Nat. Geosci., 9, 501-504, doi:10.1038/ngeo2720, 2016.

Clark, J. M., Lane, S. N., Chapman, P. J., and Adamson, J. K.: Export of dissolved organic carbon from an upland peatland during storm events: Implications for flux estimates, J. Hydrol., 347, 438-447, doi:10.1016/j.jhydrol.2007.09.030, 2007.

Clark, J. M., Lane, S. N., Chapman, P. J., and Adamson, J. $\mathrm{K}$.: Link between DOC in near surface peat and stream water in an upland catchment, Sci. Total Environ., 404, 308-315, doi:10.1016/j.scitotenv.2007.11.002, 2008.

Cole, J. J., Prairie, Y. T., Caraco, N. F., McDowell, W. H., Tranvik, L. J., Striegl, R. G., Duarte, C. M., Kortelainen, P., Downing, J. A., Middelburg, J. J., and Melack, J.: Plumbing the global carbon cycle: Integrating inland waters into the terrestrial carbon budget, Ecosystems, 10, 171-184, doi:10.1007/s10021-006-9013-8, 2007.

Cory, R. M. and McKnight, D. M.: Fluorescence spectroscopy reveals ubiquitous presence of oxidized and reduced quinones in dissolved organic matter, Environ. Sci. Technol., 39, 8142-8149, doi:10.1021/es0506962, 2005.

Cory, R. M., Ward, C. P., Crump, B. C., and Kling, G. W.: Sunlight controls water column processing of carbon in arctic fresh waters, Science, 345, 925-928, doi:10.1126/science.1253119, 2014.

Del Vecchio, R. and Blough, N. V.: Photobleaching of chromophoric dissolved organic matter in natural waters: kinetics and modeling, Mar. Chem., 78, 231-253, doi:10.1016/S03044203(02)00036-1, 2002.

Dinsmore, K. J. and Billett, M. F.: Continuous measurement and modeling of $\mathrm{CO}_{2}$ losses from a peatland stream during stormflow events, Water Resour. Res., 44, W12417, doi:10.1029/2008WR007284, 2008.

Dinsmore, K. J., Billett, M. F., Skiba, U. M., Rees, R. M., Drewer, J., and Helfter, C.: Role of the aquatic pathway in the carbon and greenhouse gas budgets of a peatland catchment, Global Change Biol., 16, 2750-2762, doi:10.1111/j.1365-2486.2009.02119.x, 2010.

Dinsmore, K. J., Billett, M. F., and Dyson, K. E.: Temperature and precipitation drive temporal variability in aquatic carbon and GHG concentrations and fluxes in a peatland catchment, Global Change Biol., 19, 2133-2148, doi:10.1111/gcb.12209, 2013.

Drewer, J., Lohila, A., Aurela, M., Laurila, T., Minkkinen, K., Penttilä, T., Dinsmore, K. J., McKenzie, R. M., Helfter, C., Flechard, C., Sutton, M. A., and Skiba, U. M.: Comparison of greenhouse gas fluxes and nitrogen budgets from an ombotrophic bog in Scotland and a minerotrophic sedge fen in Finland, Eur. J. Soil Sci., 61, 640-650, doi:10.1111/j.1365-2389.2010.01267.x, 2010.

Fellman, J. B., Hood, E., Edwards, R. T., and D'Amore, D. V.: Changes in the concentration, biodegradability, and fluorescent properties of dissolved organic matter during stormflows in coastal temperate watersheds, J. Geophys. Res.-Biogeo., 114, G01021, doi:10.1029/2008JG000790, 2009.

Fenner, N., Freeman, C., and Reynolds, B.: Observations of a seasonally shifting thermal optimum in peatland carbon-cycling processes; implications for the global carbon cycle and soil enzyme methodologies, Soil Biol. Biochem., 37, 1814-1821, doi:10.1016/j.soilbio.2005.02.032, 2005.

Fichot, C. G., Benner, R., Kaiser, K., Shen, Y., Amon, R. M. W., Ogawa, H., and Lu, C.-J.: Predicting dissolved lignin phenol concentrations in the coastal ocean from chromophoric dissolved organic matter (CDOM) absorption coefficients, Front. Mar. Sci., 3, 1-16, 2016.

Flint, S. D. and Caldwell, M. M.: A biological spectral weighting function for ozone depletion research with higher plants, Physiol. Plantarum, 117, 137-144, doi:10.1034/j.13993054.2003.1170117.x, 2003.

Fortunato, C. S., Herfort, L., Zuber, P., Baptista, A. M., and Crump, B. C.: Spatial variability overwhelms seasonal patterns in bacterioplankton communities across a river to ocean gradient, ISME J., 6, 554-563, doi:10.1038/ismej.2011.135, 2012.

Franke, D., Hamilton, M. W., and Ziegler, S. E.: Variation in the photochemical lability of dissolved organic matter in a large boreal watershed, Aquat. Sci., 74, 751-768, doi:10.1007/s00027012-0258-3, 2012.

Gordon, N. D., McMahon, T. A., Finlayson, B. L., Gippel, C. J., and Nathan, R. J.: Stream Hydrology: An Introduction for Ecologists, 2nd Edn., Wiley, West Sussex, UK, 2004.

Green, A. E. S., Sawada, T., and Shettle, E. P.: The middle ultraviolet reaching the ground, Photochem. Photobiol., 19, 251-259, doi:10.1111/j.1751-1097.1974.tb06508.x, 1974.

Häder, D.-P., Kumar, H. D., Smith, R. C., and Worrest, R. C.: Effects of solar UV radiation on aquatic ecosystems and interactions with climate change, Photoch. Photobio. Sci., 6, 267-85, doi:10.1039/b700020k, 2007.

Helms, J. R., Stubbins, A., Ritchie, J. D., Minor, E. C., Kieber, D. J., and Mopper, K.: Absorption spectral slopes and slope ratios as indicators of molecular weight, source, and photobleaching of chromophoric dissolved organic matter, Limnol. Oceanogr., 53, 955-969, doi:10.4319/lo.2008.53.3.0955, 2008.

IPCC: Summary for Policymakers, Cambridge University Press, Cambridge, 2014.

Jeanneau, L., Denis, M., Pierson-Wickmann, A.-C., Gruau, G., Lambert, T., and Petitjean, P.: Sources of dissolved organic matter during storm and inter-storm conditions in a lowland headwater catchment: constraints from high-frequency molecular data, Biogeosciences, 12, 4333-4343, doi:10.5194/bg-12-4333-2015, 2015.

Jones, T. G., Evans, C. D., Jones, D. L., Hill, P. W., and Freeman, C.: Transformations in DOC along a source to sea continuum; impacts of photo-degradation, biological processes and mixing, Aquat. Sci., 78, 433, doi:10.1007/s00027-015-0461-0, 2015.

Kendon, E. J., Roberts, N. M., Fowler, H. J., Roberts, M. J., Chan, S. C., and Senior, C. A.: Heavier summer downpours with climate change revealed by weather forecast resolution model, Nat. Clim. Change, 4, 570-576, doi:10.1038/nclimate2258, 2014.

Kent, A. D., Jones, S. E., Yannarell, A. C., Graham, J. M., Lauster, G. H., Kratz, T. K., and Triplett, E. W.: Annual patterns in bacterioplankton community variability in a Humic Lake, Microb. Ecol., 48, 550-560, doi:10.1007/s00248-004-0244-y, 2004.

Koehler, B., Landelius, T., Weyhenmeyer, G. A., Machida, N., and Tranvik, L. J.: Sunlight-induced carbon dioxide emissions from inland waters, Global Biogeochem. Cy., 28, 696-711, doi:10.1002/2014GB004850, 2014. 
Köhler, S., Buffam, I., Jonsson, A., and Bishop, K.: Photochemical and microbial processing of stream and soil water dissolved organic matter in a boreal forested catchment in northern Sweden, Aquat. Sci., 64, 269-281, doi:10.1007/s00027-002-8071-z, 2002.

Kothawala, D. N., Ji, X., Laudon, H., Ågren, A. M., Futter, M. N., Köhler, S. J., and Tranvik, L. J.: The relative influence of land cover, hydrology, and in-stream processing on the composition of dissolved organic matter in boreal streams, J. Geophys. Res., 120, 1491-1505, doi:10.1002/2015JG002946, 2015.

Lapierre, J.-F., Guillemette, F., Berggren, M., and del Giorgio, P. A.: Increases in terrestrially derived carbon stimulate organic carbon processing and $\mathrm{CO}_{2}$ emissions in boreal aquatic ecosystems, Nat. Commun., 4, 2972, doi:10.1038/ncomms3972, 2013.

Ledger, D. C.: The velocity of the River Tweed and its tributaries, Freshwater Biol., 11, 1-10, 1981.

Leith, F. I., Garnett, M. H., Dinsmore, K. J., Billett, M. F., and Heal, K. V.: Source and age of dissolved and gaseous carbon in a peatland-riparian-stream continuum: A dual isotope $\left({ }^{14} \mathrm{C}\right.$ and $\left.\delta^{13} \mathrm{C}\right)$ analysis, Biogeochemistry, 119, 415-433, doi:10.1007/s10533-014-9977-y, 2014.

Lu, C.-J., Benner, R., Fichot, C. G., Fukuda, H., Yamashita, Y., and Ogawa, H.: Sources and transformations of dissolved lignin phenols and chromophoric dissolved organic matter in Otsuchi Bay, Japan, Front. Mar. Sci., 3, 85, doi:10.3389/fmars.2016.00085, 2016.

Maranger, R. and Pullin, M. J.: Elemental complexation of dissolved organic matter in lakes: implications for Fe speciation and the bioavailability of $\mathrm{Fe}$ and $\mathrm{P}$, in: Aquatic Ecosystems: Interactivity of Dissolved Organic Matter, edited by: Findlay, S. E. G. and Sinsabaugh, R. L., Academic Press, San Diego, 185-214, 2003.

McDonnell, J. J., McGuire, K., Aggarwal, P., Beven, K. J., Biondi, D., Destouni, G., Dunn, S., James, A., Kirchner, J., Kraft, P., Lyon, S., Maloszewski, P., Newman, B., Pfister, L., Rinaldo, A., Rodhe, A., Sayama, T., Seibert, J., Solomon, K., and Soulsby, C. S.: How old is streamwater? Open questions in catchment transit time conceptualization, modelling and analysis, Hydrol. Process., 24, 1745-1754, doi:10.1002/hyp.7796, 2010.

McGuire, K. J. and McDonnell, J. J.: A review and evaluation of catchment transit time modeling, J. Hydrol., 330, 543-563, doi:10.1016/j.jhydrol.2006.04.020, 2006.

McLeod, A. R., Fry, S. C., Loake, G. J., Messenger, D. J., Reay, D. S., Smith, K. A., and Yun, B.-W.: Ultraviolet radiation drives methane emissions from terrestrial plant pectins, New Phytol., 180, 124-132, doi:10.1111/j.1469-8137.2008.02571.x, 2008.

Met Office: Met Office Integrated Data Archive System (MIDAS) Land and Marine Surface Stations Data (1853-current), NCAS Br. Atmos. Data Cent., available at: http://catalogue. ceda.ac.uk/uuid/220a65615218d5c9cc9e4785a3234bd0 (last access: 26 April 2016), 2012.

Miller, W. L. and Zepp, R. G.: Photochemical production of dissolved inorganic carbon from terrestrial organic matter: Significance to the oceanic organic carbon cycle, Geophys. Res. Lett., 22, 417-420, doi:10.1029/94GL03344, 1995.

Moody, C. S., Worrall, F., Evans, C. D., and Jones, T. G.: The rate of loss of dissolved organic carbon (DOC) through a catchment, J. Hydrol., 492, 139-150, doi:10.1016/j.jhydrol.2013.03.016, 2013.
Nguyen, M., Westerhoff, P., Baker, L., Hu, Q., EsparzaSoto, M., and Sommerfeld, M.: Characteristics and Reactivity of Algae-Produced Dissolved Organic Carbon, J. Environ. Eng., 131, 1574-1582, doi:doi:10.1061/(ASCE)07339372(2005)131:11(1574), 2005.

Opsahl, S. and Benner, R.: Photochemical reactivity of dissolved lignin in river and ocean waters, Limnol. Oceanogr., 43, 12971304, doi:10.4319/lo.1998.43.6.1297, 1998.

Opsahl, S. P. and Zepp, R. G.: Photochemically-induced alteration of stable carbon isotope ratios $\left(\delta^{13} \mathrm{C}\right)$ in terrigenous dissolved organic carbon, Geophys. Res. Lett., 28, 2417-2420, doi:10.1029/2000GL012686, 2001.

Palmer, S. M., Evans, C. D., Chapman, P. J., Burden, A., Jones, T. G., Allott, T. E. H., Evans, M. G., Moody, C. S., Worrall, F., and Holden, J.: Sporadic hotspots for physico-chemical retention of aquatic organic carbon: from peatland headwater source to sea, Aquat. Sci., 1-14, doi:10.1007/s00027-015-0448-x, 2015.

Peacock, M., Evans, C. D., Fenner, N., Freeman, C., Gough, R., Jones, T. G., and Lebron, I.: UV-visible absorbance spectroscopy as a proxy for peatland dissolved organic carbon (DOC) quantity and quality: considerations on wavelength and absorbance degradation, Environmental Science: Processes and Impacts, 10-12, doi:10.1039/c4em00108g, 2014.

Setlow, R. B.: The wavelengths in sunlight effective in producing skin cancer: a theoretical analysis, P. Natl. Acad. Sci. USA, 71, 3363-3366, doi:10.1073/pnas.71.9.3363, 1974.

Spencer, R. G. M., Aiken, G. R., Wickland, K. P., Striegl, R. G., and Hernes, P. J.: Seasonal and spatial variability in dissolved organic matter quantity and composition from the Yukon River basin, Alaska, Global Biogeochem. Cy., 22, GB4002, doi:10.1029/2008GB003231, 2008.

Spencer, R. G. M., Stubbins, A., Hernes, P. J., Baker, A., Mopper, K., Aufdenkampe, A. K., Dyda, R. Y., Mwamba, V. L., Mangangu, A. M., Wabakanghanzi, J. N., and Six, J.: Photochemical degradation of dissolved organic matter and dissolved lignin phenols from the Congo River, J. Geophys. Res., 114, G03010, doi:10.1029/2009JG000968, 2009.

Stubbins, A., Law, C. S., Uher, G., and Upstill-Goddard, R. C.: Carbon monoxide apparent quantum yields and photoproduction in the Tyne estuary, Biogeosciences, 8, 703-713, doi:10.5194/bg-8703-2011, 2011.

Sulzberger, B. and Durisch-Kaiser, E.: Chemical characterization of dissolved organic matter (DOM): A prerequisite for understanding UV-induced changes of DOM absorption properties and bioavailability, Aquat. Sci., 71, 104-126, doi:10.1007/s00027008-8082-5, 2009.

Tørseth, K., Aas, W., Breivik, K., Fjæraa, A. M., Fiebig, M., Hjellbrekke, A. G., Lund Myhre, C., Solberg, S., and Yttri, K. E.: Introduction to the European Monitoring and Evaluation Programme (EMEP) and observed atmospheric composition change during 1972-2009, Atmos. Chem. Phys., 12, 5447-5481, doi:10.5194/acp-12-5447-2012, 2012.

Tranvik, L. J., Downing, J. A., Cotner, J. B., Loiselle, S. A., Striegl, R. G., Ballatore, T. J., Dillon, P., Finlay, K., Fortino, K., Knoll, L. B., Kortelainen, P. L., Tutser, T., Larsen, S., Laurion, I., Leech, D. M., McAllister, S. L., McKnight, D. M., Melack, J. M., Overholt, E., Porter, J. A., Prairie, Y., Renwick, W. H., Roland, F., Sherman, B. S., Schindler, D. W., Sobek, S., Tremblay, A., Vanni, M. J., Verschoor, A. M., von Wachenfeldt, E., 
and Weyhenmeyer, G. A.: Lakes and reservoirs as regulators of carbon cycling and climate, Limnol. Oceanogr., 54, 2298-2314, doi:10.4319/lo.2009.54.6_part_2.2298, 2009.

Tzortziou, M., Osburn, C. L., and Neale, P. J.: Photobleaching of Dissolved Organic Material from a Tidal Marsh - Estuarine System of the Chesapeake Bay, Photochem. Photobiol., 83, 782792, doi:10.1111/j.1751-1097.2007.00142.x, 2007.

Vachon, D., Lapierre, J., and del Giorgio, P. A.: Seasonality of photochemical dissolved organic carbon mineralization and its relative contribution to pelagic $\mathrm{CO}_{2}$ production in northern lakes, J. Geophys. Res., 121, 864-878, doi:10.1002/2015JG003244, 2016.

Vähätalo, A. V. and Wetzel, R. G.: Long-term photochemical and microbial decomposition of wetland-derived dissolved organic matter with alteration of ${ }^{13} \mathrm{C}:{ }^{12} \mathrm{C}$ mass ratio, Limnol. Oceanogr., 53, 1387-1392, doi:10.4319/lo.2008.53.4.1387, 2008.

Vannote, R. L., Minshall, G. W., Cummins, K. W., Sedell, J. R., and Cushing, C. E.: The River Continuum Concept, Can. J. Fish. Aquat. Sci., 37, 130-137, doi:10.1139/f80-017, 1980.
Weishaar, J. L., Aiken, G. R., Bergamaschi, B. A., Fram, M. S., Fujii, R., and Mopper, K.: Evaluation of specific ultraviolet absorbance as an indicator of the chemical composition and reactivity of dissolved organic carbon, Environ. Sci. Technol., 37, 47024708, doi:10.1021/es030360x, 2003.

Winterfeld, M., Goñi, M. A., Just, J., Hefter, J., and Mollenhauer, G.: Characterization of particulate organic matter in the Lena River delta and adjacent nearshore zone, NE Siberia - Part 2: Lignin-derived phenol compositions, Biogeosciences, 12, 22612283, doi:10.5194/bg-12-2261-2015, 2015.

Zepp, R. G., Erickson, D. J., Paul, N. D., and Sulzberger, B.: Interactive effects of solar UV radiation and climate change on biogeochemical cycling., Photoch. Photobio. Sci., 6, 286-300, doi:10.1039/b700021a, 2007. 